\title{
Hand hygiene practice in motherland of semmelweis
}

\author{
P Cserháti \\ From 3rd International Conference on Prevention and Infection Control (ICPIC 2015) \\ Geneva, Switzerland. 16-19 June 2015
}

\section{Introduction}

The hand disinfection is the most important part of prevention in healthcare associated infections. This, and one of the WHO guidances (Global Patient Safety Challange) created our test in a Hungarian hospital where we measure the hand hygiene compliance, before and after training. We used three different methods for measurements: microbiological sampling from healthcare workers hands, inspection of the hand hygiene technique, reduction measure of the disinfectant amount.

\section{Objectives}

The purpose of the research was to check the hand disinfection habits of the healthcare workers daily routine. We would like to repeat the whole process in other Hungarian hospitals in 2015. We would like to improve hand hygiene compliance.

\section{Methods}

In case of microbiological sampling, we took samples from healthcare workers dominant hands with sterile bag technique during the workers' daily routine. 192 employees and 10 hospital department were involved in this survey and we did it before and after training. To identify the microorganisms we used differential agar plates, investigate the cultures with staining and evaluated the colonyforming units with microscope. In parallel inspected of the hand hygiene technique via Hand-in-Scan technology and measured the reduction of the disinfectant amount with help from hospital's workers. After the employee training we repeated the sampling process.

\section{Results}

After the training we experienced $\sim 30 \%$ decrease of total plate counts, the number of Escherichia coli and

Department of Disinfection, National Center of Epidemiology, Hungary
Pseudomonas aeruginosa decreased by $36 \%$ and $26 \%$. Doctors-, Nurses participant rate was $24 \%$ and $40 \%$ at first time, in case of nurses it increased to $46 \%$ at second time.

\section{Conclusion}

After the training we experienced $\sim 30 \%$ decrease of total plate counts, the number of Escherichia coli and Pseudomonas aeruginosa decreased by $36 \%$ and $26 \%$. Doctors-, Nurses participant rate was $24 \%$ and $40 \%$ at first time, in case of nurses it increased to $46 \%$ at second time.

\section{Disclosure of interest}

None declared.

Published: 16 June 2015
doi:10.1186/2047-2994-4-S1-P308

Cite this article as: Cserháti: Hand hygiene practice in motherland of semmelweis. Antimicrobial Resistance and Infection Control 2015 4(Suppl 1): P308.
Submit your next manuscript to BioMed Central and take full advantage of:

- Convenient online submission

- Thorough peer review

- No space constraints or color figure charges

- Immediate publication on acceptance

- Inclusion in PubMed, CAS, Scopus and Google Scholar

- Research which is freely available for redistribution

\section{() Biomed Central}

